\title{
The status of forest regeneration in Canada
}

\author{
by Brian Haddon ${ }^{1}$
}

The regenerating land base of Crown forest lands harvested under even-aged forest management systems since 1975 was about 14 million ha in 1995. Most harvested areas are regenerating successfully. Natural regeneration plays a much bigger role in Canadian forestry than planting or seeding. The area of forest land that remains understocked after harvesting is shrinking. The data presented were provided through the REGEN component of the National Forestry Database Program by the provincial and territorial agencies responsible for the management of forest resources in their jurisdictions.

Key words: forest inventory, forest regeneration, Canadian forests

\section{Introduction}

Regeneration of harvested lands is an important aspect of the stewardship of forest resources. This report describes the status of forest regeneration on Crown lands that were harvested under even-aged management systems between 1975 and 1995. Most Canadian forests are comprised of even-aged stands, and the trees growing

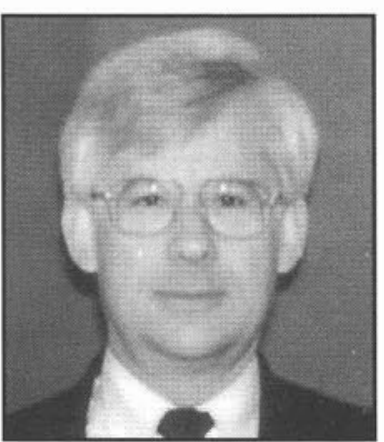
in these stands reach maturity at about the same time. These tree species are adapted to regenerate after major disturbances, such as fire. Forest management of even-aged forests attempts to mimic this life cycle.

Selection harvesting is commonly used in uneven-aged forest stands. Under these conditions, relatively small openings are created in the forest canopy to maintain an unevenaged structure with trees of all ages and sizes. Regeneration is continuous in uneven-aged stands - the stands are not replaced - and so these areas are not part of the land base described below.

The silvicultural systems used in managing even-aged forests for timber production are clearcut, seed-tree and shelterwood harvesting. Clearcutting is the most widely used silvicultural system in Canada. Selection harvesting accounted for a little over $11 \%$ of the area harvested in Canada in 1995, almost double the percentage in 1975 (Fig. 1). While clearcutting will likely remain predominant in Canada for the foreseeable future, harvesting techniques are changing. In Ontario, for example, increasing use is made of "careful logging around advanced growth". In Quebec, "cutting with protection of regeneration and soils" was mandated by the new Forest Act. This technique accounted for $22 \%$ of the area harvested under

${ }^{1}$ Manager, National Forestry Database Program, Natural Resources Canada, Canadian Forest Service, 580 Booth St., Ottawa, Ontario, Canada K1A 0E4, bhaddon@nrcan.gc.ca.
Les superficies en régénération dans les forêts publiques qui ont été récoltées selon un mode d'aménagement forestier équienne depuis 1975 totalisaient près de 14 millions d'hectares en 1995. La majeure partie des superficies récoltées se régénère adéquatement. La régénération naturelle joue un rôle plus important en foresterie au Canada que la plantation ou l'ensemencement. Les superficies qui demeurent inadéquatement stockées après la récolte diminuent d'année en année. Les données présentées ont été colligées par la composante REGEN du Programme national de données forestières et fournies par les agences provinciales et territoriales responsables de l'aménagement des ressources forestières de leur juridiction.

Mots clés: inventaire forestier, régénération forestière, forêts canadiennes

even-aged management in 1987 when the new act came into force, and $84 \%$ in 1995.

The regenerating land base of Crown lands harvested under even-aged management between 1975 and 1995 amounted to a little more than 14 million ha in 1995.

Since the 1980s, most jurisdictions have passed legislation or signed agreements which require logging companies to ensure regeneration on sites they harvest. The forest manager's options include selection cutting in forest types that are suited to uneven-aged management. In even-aged stands, the options include clearcutting and scarifying to promote natural regeneration, or adopting a modified harvesting method that will protect advance regeneration. Clearcuts may also be regenerated by planting or seeding.

Provincial planting and seeding programs were increased substantially in the 1980s under the Federal/Provincial Forest Resource Development Agreements (FRDAs) and through new legislation which enforced better regeneration practices (Fig. 2). By the early 1990s, planting programs had largely eliminated the backlog of treatable understocked sites, and several provinces began scaling back their planting programs. The notable exception is BC, which, after cutting back its planting program in 1991, increased it again to account for more than half of the 400-odd thousand ha planted across Canada in 1994 and 1995.

Today, Canadian forestry relies on advance regeneration and appropriate regeneration techniques to ensure that the majority of harvested areas will regenerate naturally. The remaining sites are regenerated by planting or seeding. Additional seedlings can be planted on sites where existing regeneration fails to meet stocking standards.

\section{Status of Forest Regeneration}

The regenerating land base evolved between 1975 and 1995 (Fig. 3) showing the status each year of the cumulative area harvested since 1975. For instance, the area shown for 1975 represents the area harvested in 1975. The area for 1976 represents the area harvested up to and including that year (1975 plus 1976), and so on. Although the annual increase in under- 


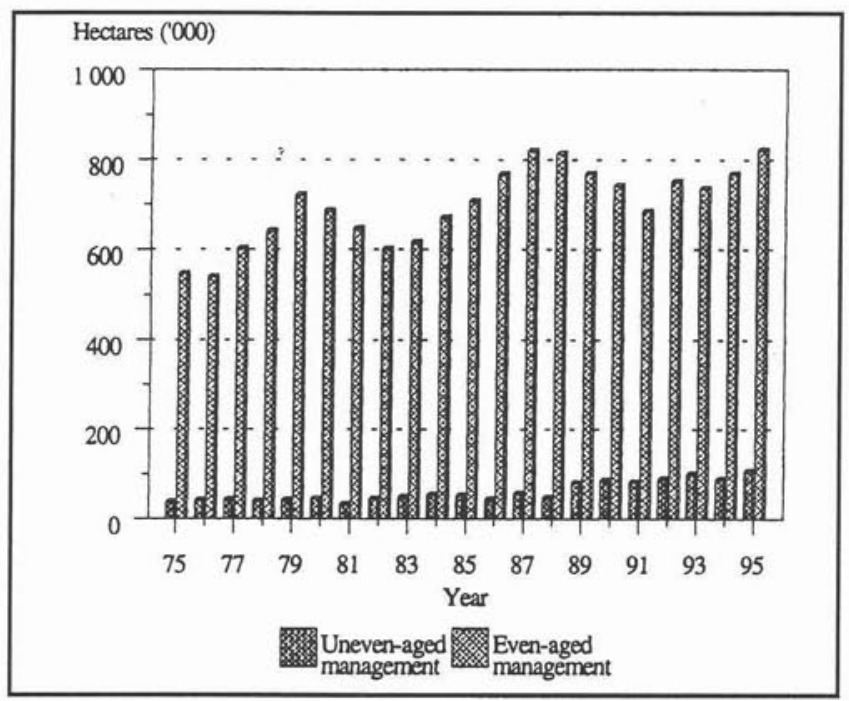

Fig. 1. Annual harvest on Crown lands.

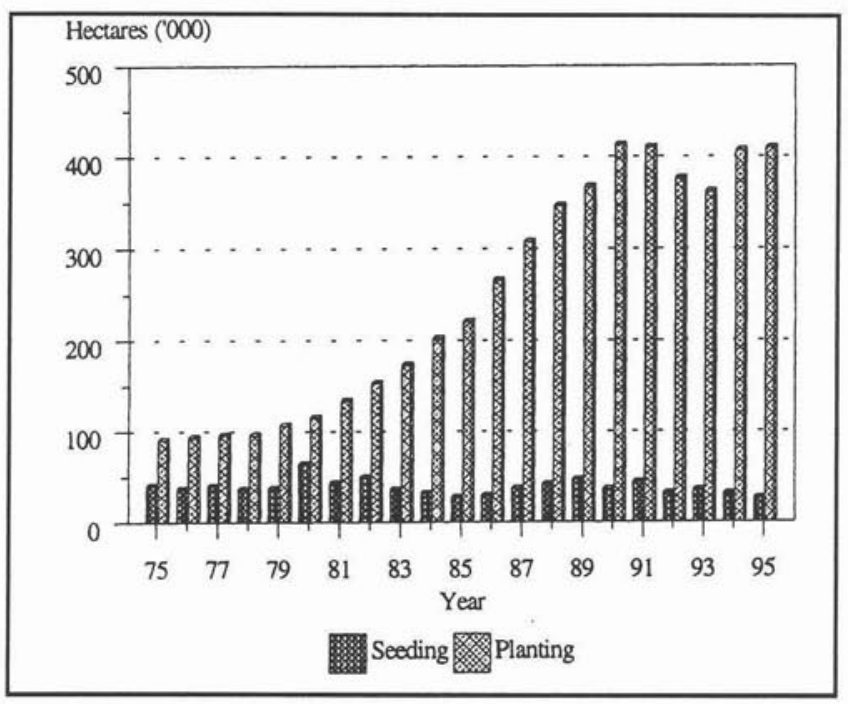

Fig. 2. Regeneration treatments.

stocked area is small, the total that has accumulated since 1975 is substantial. By 1992, it amounted to almost 2.7 million ha.

Until recently we could report on the status of forest regeneration up to 1992. At that time it appeared that the area of understocked may have actually started to decrease (Haddon et al. 1996). These data confirm that the area of understocked is gradually shrinking. By 1995, it had dropped to just under 2.6 million ha.

A significant proportion of recently harvested areas will always be reported as understocked because of the time lag between harvesting and observable results of subsequent treatments, such as planting, or natural forest stand development. The lag is evident (Fig. 4), which illustrates the regeneration status in 1995 of the area harvested each year since 1975 . The area that is reported as understocked for status year 1995 amounts to a little more than the three years' harvest between 1993 and 1995.

The area shown (Fig. 5) for 1975 represents the area harvested in 1975, while the area for 1976 represents the status

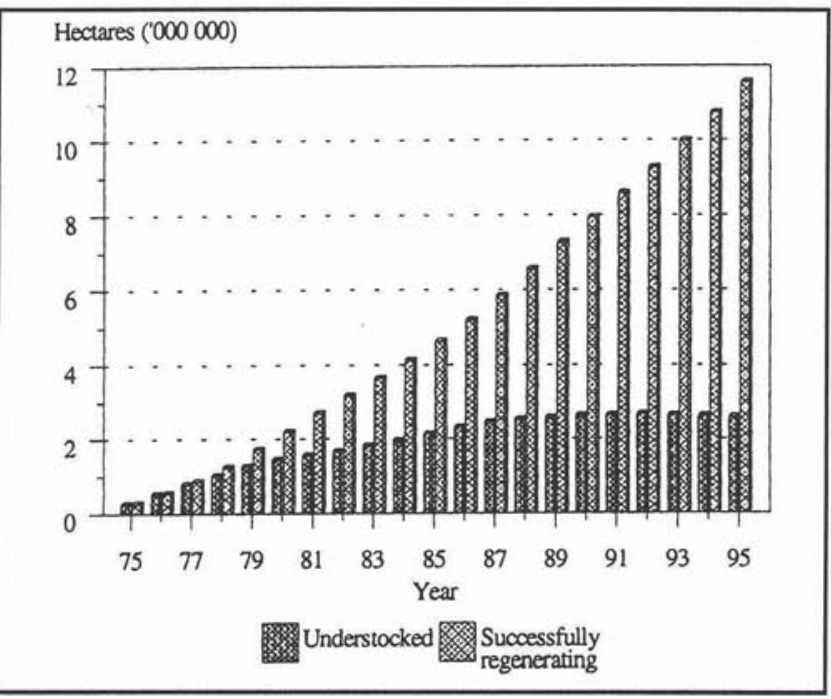

Fig. 3. Status of forest regeneration on Crown land.

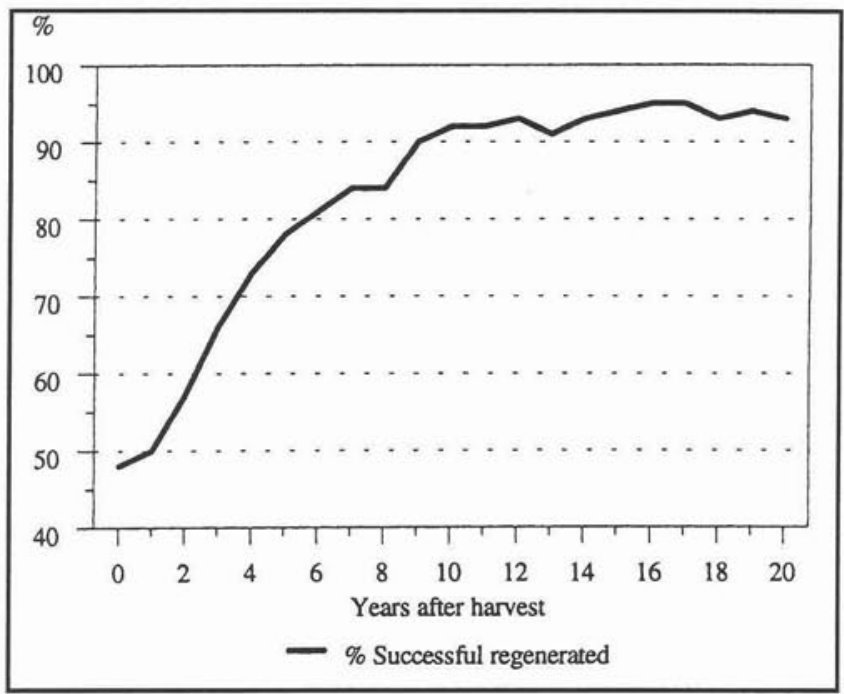

Fig. 4. Regeneration status in 1995.

in 1976 of the area harvested up to and including that year, and so on. In this graph, the proportion of the area that regenerated naturally and as a result of planting or seeding is illustrated by the columns, while the area harvested is shown as a line. It is evident that natural regeneration plays a much larger role in Canadian forestry than does planting or seeding. The space between the line and the top of the column is the area that remained understocked each year.

The National Forestry Database Program (NFDP) describes regeneration status in terms of nine classes which relate to the level of stocking of commercial tree species, their distribution and the degree to which they are affected by competing vegetation. The classes are usually aggregated to report on regeneration status, but it is also possible to analyse the evolution of the regenerating land base in terms of regeneration status classes. The dynamic nature of the forest cycle means that the distribution of regeneration classes is continually changing. The regeneration status is illustrated (Fig. 6) for 1995 of the forest land harvested in each year between 1975 and 1995 . Forest 


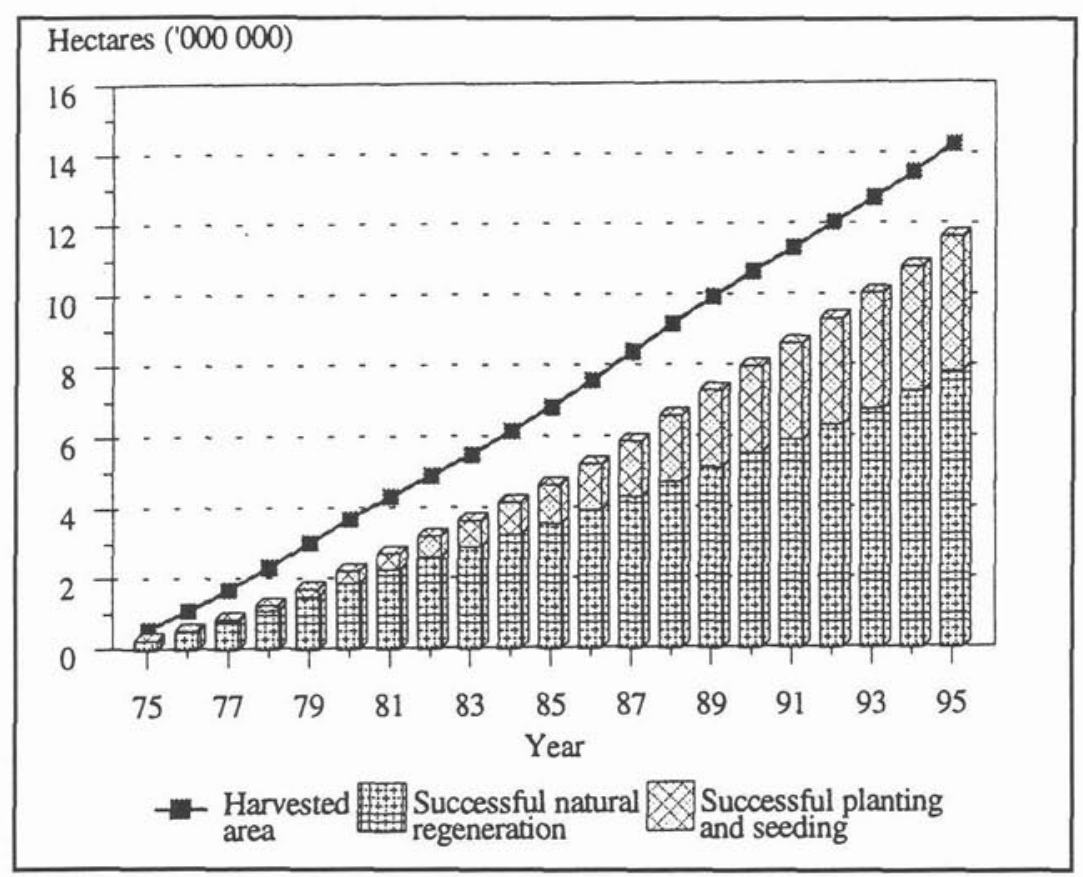

Fig. 5. Regeneration of Crown lands in Canada, 1975-1995.

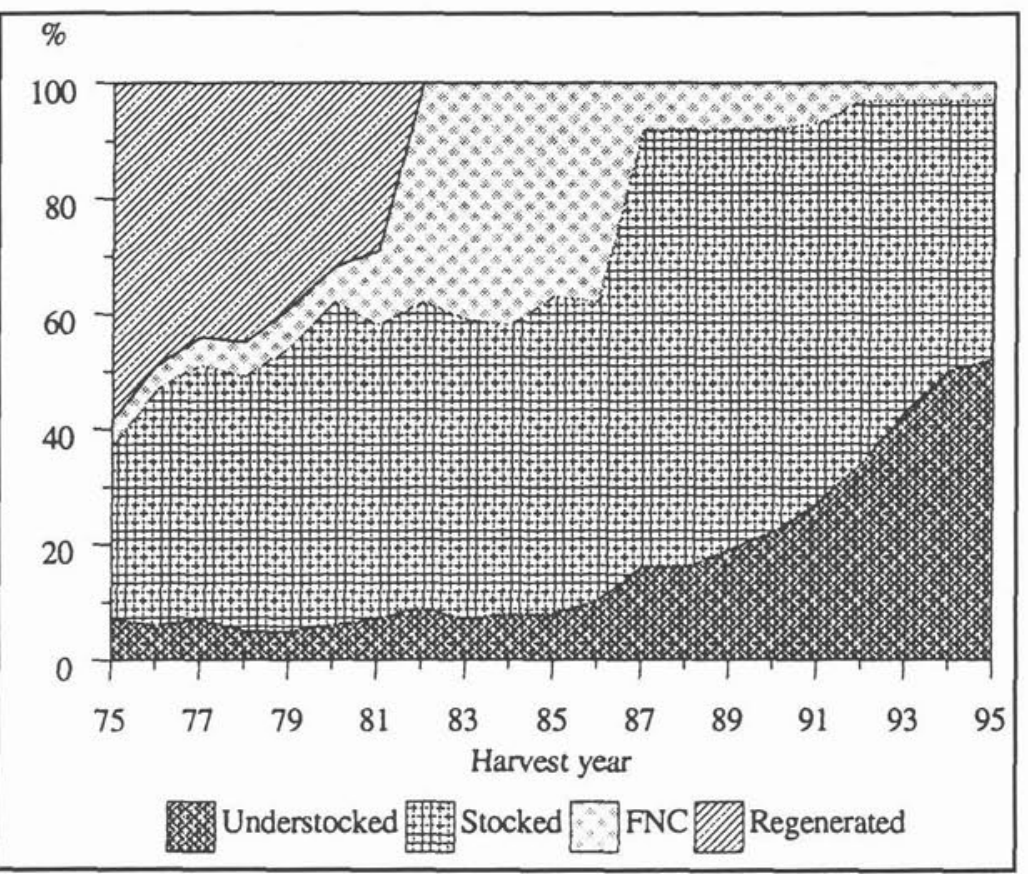

Fig. 6. Evolution of the regeneration land base (Regeneration status in 1995).

regeneration on land harvested in earlier years has had time to develop to the higher classes. Land harvested in later years may not have been treated by 1995 , and natural regeneration has not had time to develop beyond the stocked class.

The understocked class is defined as those harvested areas that will require silvicultural treatment to meet stocking standards. It includes unsurveyed harvest areas where regeneration status cannot be predicted. Stocked areas are harvest areas that have regenerated naturally or by planting or seeding. This class includes a proportion of recently harvested areas which are expected to become restocked without further treatment. The concept of free-from-non-crop competition is the same as the concept of free-to-grow in several jurisdictions. For purposes of this discussion, this class is defined as areas where the regenerating stand has achieved freedom from competition (from non-crop species) that impedes growth. The regenerated class can be viewed as the culmination of the regeneration process. It is those areas where silvicultural objectives have been met, and long-term timber production objectives will be achieved.

\section{REGEN: A Program for Reporting on Regeneration Results}

The National Forestry Database Program was established in 1990 by the Canadian Council of Forest Ministers with three objectives:- to establish a national database that describes forest management and its impact on the forest resource; to develop a public information program based on the data- 
base; and to provide reliable, timely information to the provincial and federal policy processes.

The REGEN component of the database program was designed to use the best available information. In British Columbia, for example, every harvested area is surveyed after a prescribed number of years to confirm its regeneration status. In many jurisdictions, however, the only available information is the results of sample surveys. From these samples, the forest management agencies can model expected results based on the areas harvested and how they were subsequently treated. A more comprehensive description of REGEN's background and conceptual model is provided in Haddon et al. (1996).

The data presented in this article were provided by the provincial and territorial agencies responsible for the management of forest resources in their jurisdictions.

\section{Acknowledgements}

The success of the REGEN program is due to the support of the National Forestry Database Program (NFDP) Steering Committee, and especially to the work of the NFDP Technical Subcommittee on Reporting Regeneration Results. Subcommittee members faced many problems in establishing the necessary databases for their respective agencies, and in develop- ing protocols to ensure that their information is compatible and comparable so that reporting at the national level is accurate and meaningful. The subcommittee members in March, 1997 were Kerri Brownie (British Columbia Ministry of Forests), Lindsay Kerkhoff (Alberta Department of Environmental Protection), Henry Desjarlais (Saskatchewan Department of Environment and Resource Management), Jeff Delaney (Manitoba Department of Natural Resources), John McCaugherty (Ontario Ministry of Natural Resources), François Trottier (Ministère des Ressources naturelles du Québec), John Upshall (New Brunswick Department of Natural Resources and Energy), Brian White (Nova Scotia Department of Natural Resources), Jon Hutchinson (Prince Edward Island Department of Agriculture, Fisheries and Forestry), Ivan Downton (Newfoundland Department of Forest Resources and Agrifoods), Debra Wortley (Yukon Forest Resources, Indian and Northern Affairs Canada), and Tim Keddy (Northwest Territories Department of Resources, Wildlife and Economic Development). The author wishes to express his appreciation to Jacquelin Olivier for preparing the figures which appear in this article.

\section{References}

Haddon, B.D., F. Sauvageau and E. Wang. 1996. REGEN: A program for reporting on forest regeneration. For. Chron. 72(5): $505-512$. 